\title{
Additives incorporated into urea to reduce nitrogen losses after application to the soil
}

\author{
Ioná Rech(1), José Carlos Polidoro(2) and Paulo Sérgio Pavinato(1)
}

\begin{abstract}
(1)Universidade de São Paulo, Escola Superior de Agricultura Luiz de Queiroz, Avenida Pádua Dias, no 11, Caixa Postal 9, CEP 13418-900 Piracicaba, SP, Brazil. E-mail: agr.rech@gmail.com, pavinato@usp.br ${ }^{(2)}$ Embrapa Solos, Rua Jardim Botânico, № 1.024, Jardim Botânico, CEP 22460-000 Rio de Janeiro, RJ, Brazil. E-mail: jose.polidoro@embrapa.br
\end{abstract}

\begin{abstract}
The objective of this work was to develop urea-based fertilizers with internal incorporation of urease inhibitors and other additives in the granule. The effects of the incorporation of NBPT, copper $\left(\mathrm{Cu}^{+2}\right)$, boric acid $\left(\mathrm{H}_{3} \mathrm{BO}_{3}\right)$, elemental sulphur $\left(\mathrm{S}^{\circ}\right)$, and a clay mineral from the zeolite group in powder urea - with ten different combinations of these additives - were evaluated as to $\mathrm{N}$ losses by volatilization and leaching. The losses in laboratory-developed formulations were compared with those of commercial fertilizers coated with the same additives (Super N, FH Nitro Mais, and FH Nitro Gold). The evaluations were made in greenhouse conditions, using a Ultisol accommodated in PVC columns. Nitrate and ammonium leaching was evaluated in the solution percolated through the soil columns. Ammonia volatilization was measured with a semi-open static chamber. The incorporation of urease inhibitors $\left(\mathrm{NBPT}, \mathrm{H}_{3} \mathrm{BO}_{3}\right.$, and $\left.\mathrm{Cu}^{+2}\right)$ into the urea granules was efficient to reduce $\mathrm{N}$ volatilization. Ammonia volatilization in the laboratory-developed ureas was lower than in commercial fertilizers coated with the same additives, while ammonium sulfate losses by leaching were similar. The addition of zeolite does not reduce $\mathrm{N}$ volatilization. Mineral $\mathrm{N}$ leaching in the soil profile is not affected by urease inhibitors.
\end{abstract}

Index terms: ammonia volatilization, leaching, NBPT, nitrogen fertilizers, urease inhibitors.

\section{Aditivos incorporados à ureia para reduzir perdas de nitrogênio após aplicação ao solo}

Resumo - O objetivo deste trabalho foi desenvolver fertilizantes à base de ureia com a incorporação interna no grânulo de inibidores de urease e outros aditivos. Os efeitos da incorporação de NBPT, cobre $\left(\mathrm{Cu}^{+2}\right)$, ácido bórico $\left(\mathrm{H}_{3} \mathrm{BO}_{3}\right)$, enxofre elementar $\left(\mathrm{S}^{\circ}\right)$ e um mineral de argila do grupo das zeólitas na ureia em pó - com dez diferentes combinações desses aditivos - foram avaliados quanto às perdas por volatilização e lixiviação. As perdas nas formulações desenvolvidas em laboratório foram comparadas com as de fertilizantes comerciais revestidos com os mesmos aditivos (Super N, FH Nitro Mais e FH Nitro Gold). As avaliações foram realizadas em casa de vegetação, tendo-se utilizado um Argissolo Vermelho, o qual foi acondicionado em colunas de PVC. A lixiviação de nitrato e amônio foi avaliada na solução percolada através das colunas do solo. A volatilização da amônia foi estimada por meio de uma câmara estática semiaberta. A incorporação de inibidores de urease $\left(\mathrm{NBPT}, \mathrm{H}_{3} \mathrm{BO}_{3}\right.$ e $\left.\mathrm{Cu}^{+2}\right)$ nos grânulos de ureia foi eficiente para reduzir a volatilização de N. A volatilização de amônia das ureias desenvolvidas em laboratório foi menor do que nos fertilizantes comerciais revestidos com os mesmos aditivos, enquanto as perdas do sulfato de amônio por lixiviação foram semelhantes. A adição da zeólita não reduz a volatilização de $\mathrm{N}$. A lixiviação de $\mathrm{N}$ mineral no perfil do solo não é afetada pelos inibidores de urease.

Termos para indexação: volatilização de amônia, lixiviação, NBPT, fertilizantes nitrogenados, inibidores de urease.

\section{Introduction}

Urea $\left[\mathrm{CO}\left(\mathrm{NH}_{2}\right)_{2}\right]$ is the main nitrogen fertilizer used in agriculture, accounting for $60 \%$ of the commercialized $\mathrm{N}$ fertilizers worldwide (Heffer \& Prud'homme, 2015). However, the main concern for agricultural use of this fertilizer is its high $\mathrm{N}$ losses through ammonia $\left(\mathrm{NH}_{3}\right)$ volatilization when applied on soil surface, after the hydrolysis reaction catalyzed by urease enzyme (Chien et al., 2009).

$\mathrm{NH}_{3}$ losses from urea depend on temperature, humidity, soil $\mathrm{pH}$ and presence of crop residues on soil surface, which increase urease activity in the soil (Frankenberger Jr. \& Tabatabai, 1982; Watson et al., 
2008). High $\mathrm{N}$ losses are observed in humid regions, like Brazil, commonly reaching up to $20-30 \%$ of the total $\mathrm{N}$ applied via fertilizer; or even higher, around 60\% (Cantarella et al., 2008; Rochette et al., 2013).

Urease activity is the greatest regulator of $\mathrm{NH}_{3}$ volatilization, and it can be inhibited by complexing the enzyme with small molecules or with specific ions during the fertilizer formulation. Thus, urease inhibitors like $\mathrm{N}$-(n-butyl) thiophosphoric triamide (NBPT), copper $\left(\mathrm{Cu}^{+2}\right)$ and boric acid $\left(\mathrm{H}_{3} \mathrm{BO}_{3}\right)$, as well as polymers and elemental sulphur that interfere with solubilization, have been studied to reduce $\mathrm{N}$ losses by volatilization ( $\mathrm{Du}$ et al., 2008; Trenkel, 2010; Soares et al., 2012; Nascimento et al., 2013). Moreover, clay minerals of the zeolite group are currently being tested with the same objective. These clay minerals present some cation exchange capacity (CEC), which is responsible for $\mathrm{NH}_{4}{ }^{+}$retention in the soil and for its gradual release to the soil solution (Calvo et al., 2009). According to Bernardi et al. (2007), urea mixtures with $25 \%$ of zeolite improved $\mathrm{N}$ use by plants, especially with higher application rates.

Commercial fertilizers like Super N, FH Nitro Mais, and FH Nitro Gold have NBPT, $\mathrm{CuSO}_{4}+\mathrm{H}_{3} \mathrm{BO}_{3}$, and $\mathrm{S}^{\circ}$ as surface coating of their granules, respectively. The incorporation of these urease inhibitors into the granules has not yet been evaluated as an alternative to maximize the control of urea $\mathrm{NH}_{3}$ losses. Therefore, this study can help improve the production process of these fertilizers by adding these additives internally in the composition of the granules. This process is already being explored in some high efficiency fertilizers (resin or membrane coated fertilizers), which, however, have impeditive prices for large scale agricultural crops.

The objective of this work was to develop ureabased fertilizers with internal incorporation of urease inhibitors and other additives in the granule, in order to minimize $\mathrm{N}$ losses through ammonia volatilization or ammonium and nitrate leaching.

\section{Material and Methods}

The experiment was carried out in a greenhouse at the Soil Science Department of the Escola Superior de Agricultura "Luiz de Queiroz" (Esalq, USP), in the municipality of Piracicaba, state of São Paulo, Brazil, in the first semester of 2013. The 0-0.20-m layer of a Ultisol (Argissolo Vermelho, according to the Brazilian classification) was used, collected from the research cropping area of the institution $\left(22^{\circ} 46^{\prime} 08^{\prime \prime} \mathrm{S}\right.$; $\left.47^{\circ} 37^{\prime} 03^{\prime \prime} \mathrm{W}\right)$.

Soil chemical analysis was performed according to Raij et al. (2001), with the following results: $\mathrm{pH}$ $\left(\mathrm{CaCl}_{2}\right), 5.2$; organic matter $(\mathrm{OM})$, determined by carbon oxidation with potassium dichromate, $22 \mathrm{~g} \mathrm{~kg}^{-1}$; ion exchange resin of $\mathrm{P}, \mathrm{K}, \mathrm{Ca}$, and $\mathrm{Mg}$, respectively, of $23 \mathrm{mg} \mathrm{dm}^{-3}, 1.8 \mathrm{mmol}_{\mathrm{c}} \mathrm{dm}^{-3}, 23 \mathrm{mmol}_{\mathrm{c}} \mathrm{dm}^{-3}$, and $8 \mathrm{mmol}_{\mathrm{c}} \mathrm{dm}^{-3}$; $\mathrm{S}$ extracted with ammonium acetate $0.5 \mathrm{~mol} \mathrm{~L}^{-1}\left(\mathrm{~S}_{-} \mathrm{SO}_{4}\right)$ of $4 \mathrm{mg} \mathrm{dm}^{-3}$; $\mathrm{B}$ determined in hot water of $0.16 \mathrm{mg} \mathrm{dm}^{-3}$; DTPA extracted $\mathrm{Cu}, \mathrm{Fe}, \mathrm{Mn}$, and $\mathrm{Zn}$ respectively of $1.5 \mathrm{mg} \mathrm{dm}^{-3}, 51 \mathrm{mg} \mathrm{dm}^{-3}, 11.8$ $\mathrm{mg} \mathrm{dm}{ }^{-3}$, and $2.9 \mathrm{mg} \mathrm{dm}^{-3} ; \mathrm{Al}^{3+}$ extracted by $\mathrm{KCl}, 0$ $\mathrm{mmol}_{\mathrm{c}} \mathrm{dm}^{-3}$; CEC, $48 \mathrm{mmol}_{\mathrm{c}} \mathrm{dm}^{-3}$; and $\mathrm{V}, 69 \%$. Soil textural composition was formed by 178.2, 17.1, and $804.7 \mathrm{~g} \mathrm{~kg}^{-1}$ of clay, silt and sand, respectively. Predominant minerals in the clay fraction were kaolinite and iron/aluminum oxides.

The experimental units were formed by $50 \times 15 \mathrm{~cm}$ PVC columns. The column bottom of each PVC pipe was closed with a cap allowing a $0.5 \mathrm{~cm}$ diameter hole to collect the leached solution. An acrylic blanket was allocated at the bottom to avoid soil losses and to filter the percolated solution. Each pipe was filled with $8.2 \mathrm{~kg}$ of soil, up to the $45-\mathrm{cm}$ height; then, the soil was saturated with deionized water and kept in $70-90 \%$ of the water retention capacity throughout the experimental period, by periodically weighing the columns.

The water retention capacity of the soil in the columns was determined by the difference between saturated and dried soil. Thus, a column with approximately $3 \mathrm{~L}$ of water was added to reach saturation of the $8.2 \mathrm{~kg}$ of soil conditioned in the PVC. The weighing was performed after a 48 -hour drainage period. The water retention capacity in the soil was determined by the formula $U(\%)=(\mathrm{Msu}-\mathrm{Mss}) / \mathrm{Mss}$, where Msu is the mass of damp soil, and Mss is the mass of dried soil $(\mathrm{U}=28 \%$ in the evaluated soil).

The incorporation of urea plus additives in laboratory was performed in the Laboratory of Fertilizer Technologies of Embrapa Solos, a unit of the Brazilian Agricultural Research Corporation (Embrapa), in municipality of Rio de Janeiro, state of Rio de Janeiro, Brazil. Commercial urea with diameter between 1 and $2 \mathrm{~mm}$, micronized in a chamber mill for thermostatization with cooled chilled water, model 
MA.090/CFT (Marconi, Piracicaba, SP, Brazil), was used to produce ten different formulations, with the following additives internally incorporated to the fertilizer powder: boric acid $\left(\mathrm{H}_{3} \mathrm{BO}_{3}\right)$, copper $\left(\mathrm{CuSO}_{4}\right)$, and elemental sulphur $\left(\mathrm{S}^{\circ}\right)$. The additives were incorporated in the same amount of the products already being used to coat the urea granule in some commercial formulations: $\mathrm{B}, 0.15 \%$; $\mathrm{Cu}, 0.4 \%$; and $\mathrm{S}, 16 \%$. Agrotain commercial fertilizer contains the urease inhibitor N-butyl thiophosphoric triamide (NBPT) in a proportion of $2.5 \mathrm{~L}$ of the product per ton of urea; thus, NBPT was also added to the powdered urea in liquid form, with a sprinkler, in the same proportion, correspondent to $2.5 \mathrm{~mL}$ of the product per $\mathrm{kg}$ of urea. Moreover, the clay mineral clinoptilolite (Celta Brasil, Cotia, SP, Brazil), from the zeolite group, was added in the proportion of $20 \%$ of the mixture, in the mass of powdered urea.

The incorporation of additives was performed in a V-type mixer, and then they were granulated. The granulation was done in a small-sized pelletizer with a 400-mm diameter plate, similar to the industrial largescale fertilizer granulator. The estimated zeolite CEC $\left(140 \mathrm{cmol}_{\mathrm{c}} \mathrm{dm}^{-3}\right)$ was determined according to Richards (1954), and the density $\left(0.224 \mathrm{~g} \mathrm{dm}^{-3}\right)$ was obtained from Celta Brasil. The specific surface $\left(11.4 \mathrm{~m}^{2} \mathrm{~g}^{-1}\right)$ was determined with the Quantachrome apparatus, with high-speed gas sorption analyzer, using the BET surface area and pore size analyzer (Brunauer et al., 1938), with the aid of the NovaWin program.

The ten laboratory-developed formulations (Table 1), with the theoretical percentages of each additive, are described as follows: urea plus zeolite (20\%); urea plus NBPT $(0.25 \%)$; urea plus $\mathrm{S}^{\circ}(16 \%)$; urea plus B $(0.4 \%)$ and $\mathrm{Cu}(0.15 \%)$; urea plus NBPT $(0.2 \%)$ and $\mathrm{Cu}(0.14 \%)$; urea plus $\mathrm{Cu}(0.15 \%)$; urea plus $\mathrm{B}(0.3 \%), \mathrm{Cu}(0.11 \%)$, and zeolite $(20 \%)$; urea plus NBPT $(0.2 \%)$ and zeolite (20\%); urea plus $\mathrm{S}^{\circ}(11.2 \%)$ and zeolite (17.5\%); and urea plus NBPT $(0.19 \%), \mathrm{Cu}$ $(0.11 \%)$, and zeolite $(19.9 \%)$. Other six treatments were formed by the five commercial fertilizers that use these inhibitors externally coating the urea granules. The commercial fertilizers were used as a baseline for comparison.

For the formulations urea plus NBPT $(0.25 \%)$, urea plus $\mathrm{B}(0.4 \%)$ and $\mathrm{Cu}(0.15 \%)$, and urea plus NBPT $(0.2 \%)$ and zeolite $(20 \%)$, a patent request was applied at Brazil's institute of industrial property (Instituto
Nacional da Propriedade Industrial, INPI), under the title: "Micronized urea-based fertilizers and their achievement process" (Embrapa \& Universidade de São Paulo, 2016).

The chemical analysis of the total contents of N, S, $\mathrm{B}$ and $\mathrm{Cu}$ in the formulations of urea and additives, as well as in the commercial products (Table 1), was performed according to the official methods of fertilizer analysis of the Brazilian Ministry of Agriculture, Livestock and Food Supply (Brasil, 2007).

The treatments were applied 10 days after soil incubation, a period preserved for biota acclimatization and enzyme activity reactivation in soil, since the soil had been previously air dried and sieved at $2 \mathrm{~mm}$. A completely randomized design with four replicates was used, totaling 64 experimental units (PVC pipes). The fertilizers were evenly applied on the soil surface of each column, at $120 \mathrm{~kg} \mathrm{ha}^{-1} \mathrm{~N}$ rate.

Volatilized $\mathrm{NH}_{3}$ was quantified in a semi-open static collector, developed by Nömmik (1973) and adapted by Lara Cabezas et al. (1999), top-fixed to each soil column immediately after fertilizer application. The foam from the collector was collected 1, 2, 3, 4, 5, 7, 9,

Table 1. Treatment description and analytical results for nitrogen, copper, boron, and elemental sulphur in the laboratory-developed formulations and in the commercial $\mathrm{N}$ fertilizers used in the study.

\begin{tabular}{lccccc}
\hline Treatment & Composition & $\mathrm{N}$ & $\mathrm{Cu}$ & $\mathrm{B}$ & $\mathrm{S}$ \\
& & -------- & $(\%)$ & -------- \\
\hline U_Z-i & Urea+Zeolite & 35.2 & - & - & - \\
U_NBPT-i & Urea+NBPT & 43.3 & - & - & - \\
U_S-i & Urea+Elemental S & 35.5 & - & - & 14.6 \\
U_BCu-i & Urea+B+Cu & 41.9 & 0.13 & 0.38 & - \\
U_NBPTCu-i & Urea+NBPT+Cu & 42.7 & 0.13 & - & - \\
U_Cu-i & Urea+Cu & 44.3 & 0.14 & - & - \\
U_BCuZ-i & Urea+B+Cu+Zeolite & 37.2 & 0.10 & 0.27 & \\
U_NBPTZ-i & Urea+NBPT+Zeolite & 35.1 & - & - & - \\
U_SZ-i & Urea+Elemental S+Zeolite & 30.7 & - & - & 10.2 \\
U_NBPTCuZ-i & Urea+NBPT+Cu+Zeolite & 34.5 & 0.11 & - & - \\
U & Commercial pearly urea & 43.9 & - & - & - \\
Super N & Urea+NBPT & 42.4 & - & - & - \\
FH Nitro Mais & Urea+B+Cu & 43.1 & 0.14 & 0.39 & - \\
FH Nitro Gold & Urea+S & 37.5 & - & - & 15.1 \\
AS & Ammonium sulfate & 19.3 & - & - & - \\
Control & No fertilizer & - & - & - & - \\
\hline
\end{tabular}


$11,13,15,18,22$, and 29 days after fertilizer application, totaling 13 samplings. At each sampling, the top foams were discarded and the bottom ones were stored in plastic bags in a freezer $\left(-7^{\circ} \mathrm{C}\right)$ until extraction and analysis. For the extraction, the foams were washed with deionized water in a Büchner funnel with porous filter plate, using a Kitasato flask and a vacuum pump. Final volume was quantified and a $50-\mathrm{mL}$ aliquot was stored in Falcon tubes for later $\mathrm{N}_{-} \mathrm{NH}_{3}$ determination. The $\mathrm{N}-\mathrm{NH}_{3}$ concentration was determined using an autosampler linked to a Flow Injection Analysis (FIA) device (Kamogawa \& Teixeira, 2009).

After 29 days of $\mathrm{N}^{-\mathrm{NH}_{3}}$ volatilization, ammonium and nitrate leaching were estimated in the soil columns. For that, soil water content was raised to saturation, by weighing the columns and adding distilled water. This procedure was done in order to standardize the soil columns humidity. Then, more water was added in order to allow the outflow of leached solution for $\mathrm{N}$ measurement.

Distilled water was added to simulate a $15 \mathrm{~mm}_{\text {day }}{ }^{-1}$ precipitation, equivalent to $0.264 \mathrm{~L}$ per column, during four consecutive days. The leached solution was collected in recipients containing $3 \mathrm{~mL}$ of $\mathrm{HCl}(1 \%)$, fixed under the soil columns. This acidification aimed at stabilizing $\mathrm{N}$ as ammonium or nitrate in the solution. This leached solution was measured and filtered; then, a 50-mL aliquot was stored in Falcon tubes in a freezer $\left(-7^{\circ} \mathrm{C}\right)$. The ammonium concentration in the leached solution was analyzed by FIA (Kamogawa \& Teixeira, 2009). Nitrate concentration was determined with the spectrophotometric method, according to Olsen (2008).

Right after the evaluations on leached solutions, soil samples were collected with a probe, in the layers $0-0.10,0.10-0.20$, and $0.20-0.45 \mathrm{~m}$. The samples were homogenized and stored in a freezer $\left(-7^{\circ} \mathrm{C}\right)$. Ammonium and nitrate in the soil were extracted with $\mathrm{KCl} 1 \mathrm{~mol} \mathrm{~L}^{-1}$ (Silva, 2009). Soil $\mathrm{NH}_{4}{ }^{+}$concentration was quantified by FIA (Kamogawa \& Teixeira, 2009). Soil nitrate was determined with the spectrophotometric method (Olsen, 2008).

$\mathrm{N}$ losses and $\mathrm{N}$ accumulation data were subjected to the analysis of variance, using SAS 8.1 program (SAS Institute Inc., Cary, NC, USA). The means were compared using the Scott-Knott test, at 5\% probability.

\section{Results and Discussion}

Ammonia volatilization data of the urea formulations evaluated were distinct (Figure 1). Regardless of the formulation, the highest volatilization rates were observed between the second and the fourth day after application. The urea hydrolysis in the present study was facilitated by soil humidity and temperature (minimum average of $19^{\circ} \mathrm{C}$ and maximum average of $33.5^{\circ} \mathrm{C}$ ). The formulations with highest loss peaks in this initial period were, in decreasing order: urea plus zeolite (U Z-i), commercial urea (U), urea plus $\mathrm{S}^{\mathrm{o}}$ (U_S-i), and commercial fertilizer FH Nitro Gold (coated with elemental S). The lowest peaks of volatilization were observed in the laboratorydeveloped formulations, where the following stood out positively: urea plus NBPT (U_NBPT-i), urea plus NBPT and zeolite (U_NBPTZ-i), and urea plus $\mathrm{B}$ and $\mathrm{Cu}$ (U_BCu-i). The other commercial and laboratory-developed formulations had intermediate $\mathrm{NH}_{3}$ volatilization losses.

The fertilizers with the highest accumulated $\mathrm{N}$ losses by volatilization were commercial urea (U), commercial urea coated with elemental S (FH Nitro Gold), and urea plus zeolite (U_Z-i), and they did not differ statistically from each other (Table 2). The laboratory-incorporated formulations with urease inhibitors NBPT, B, and Cu (U_NBPT-i, U_NBPTZ-i, and $\mathrm{U} B C u-i)$ were statistically similar to the ammonium sulfate (AS) and to the control (C) (Figure 1 and Table 2). These three formulations were more efficient in reducing volatilization than the commercial fertilizers Super N and FH Nitro Mais, which use the same inhibitors coating the granule, instead of internally incorporated to it.

Incorporation of zeolite together with the urease inhibitors $\mathrm{B}$ and $\mathrm{Cu}$ (U_BCuZ-i) increased the volatilization, compared to the formulations without zeolite (U BCu-i), but it was statistically similar to the commercial urea coated with $\mathrm{B}$ and $\mathrm{Cu}(\mathrm{FH}$ Nitro Mais) and Super N, as well as to the laboratory formulation U_Cu-i. The formulations $U_{-} \mathrm{Cu}-\mathrm{i}$ and U_BCuZ-i were statistically similar to the commercial fertilizers Super N and FH Nitro Mais. The other laboratory-incorporated formulations with sulphur, U_Z-i and U_S-i, showed expressive losses compared to AS. However, these losses were much lower than in commercial urea (Table 2).

Pesq. agropec. bras., Brasília, v.52, n.3, p.194-204, mar. 2017 DOI: 10.1590/S0100-204X2017000300007 
Combination of NBPT and $\mathrm{Cu}$ in the urea (U NBPTCu-i) - which are additives that inhibit different action mechanisms of volatilization - and this same formulation plus zeolite (U_NBPTCuZ-i) had similar results, and did not differ statistically from the formulations U_SZ-i and U_S-i. These laboratorydeveloped formulations reduced the volatilization compared to commercial urea, but were less efficient to reduce $\mathrm{N}$ volatilization than other laboratoryincorporated formulations tested, as already mentioned.

As already known, urea applied on soil surface has a high potential for $\mathrm{N}$ losses by volatilization. Urea hydrolysis is directly correlated to the increase in soil moisture (Kelliher et al., 2008; Tasca et al., 2011; Cancellier et al., 2016). In this work, the soil was kept at all times under high moisture conditions, which may have favored higher volatilization than that in the crop field. Werneck et al. (2012), working in field with adequate moisture level for crop growth, but with high temperature, reported a substantial $\mathrm{NH}_{3}$ volatilization from urea, which peaked between the first and the third day after fertilizer application. This behavior was also observed in the present study. In all cases, the loss peak happened between the second and the fourth day after fertilizer application.

The laboratory-incorporated fertilizers with urease inhibitors (NBPT, B and Cu), U_NBPT-i and $\mathrm{U}_{-} \mathrm{BCu}-\mathrm{i}$ were more efficient to control the volatilization compared to the commercial fertilizers coated with these additives (Super $\mathrm{N}$ and FH Nitro Mais) (Table 2). Cantarella et al. (2008) reported N losses by volatilization around $25 \%$ in commercial urea and $15 \%$ in urea coated with NBPT. Reports

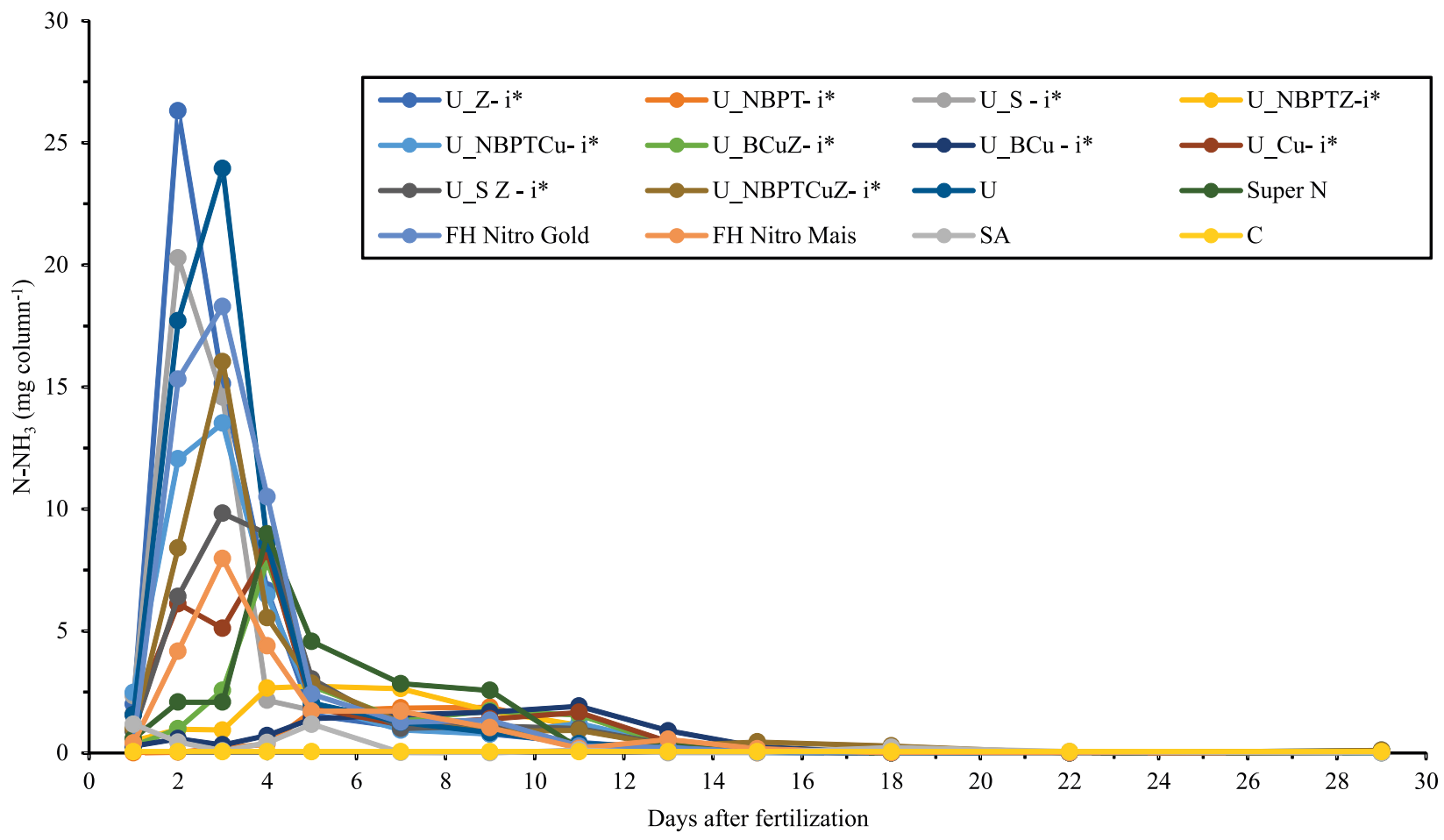

Figure 1. Daily $\mathrm{N}_{-} \mathrm{NH}_{4}{ }^{+}$volatilization rate from the evaluated nitrogen fertilizers: U_Z-i, urea+zeolite incorporated; U_NBPT-i, urea+NBPT incorporated; U_S-I, urea+elemental sulphur incorporated; U_BCu-i, urea+B+Cu incorporated; U_NBPTCu-I, urea+NBPT $+\mathrm{Cu}$ incorporated; U_Cu-i, urea $+\mathrm{Cu}$ incorporated; U_BCuZ-i, urea $+\mathrm{B}+\mathrm{Cu}+$ zeolite incorporated; U_NBPTZ-i, urea+NBPT+zeolite incorporated; U_SZ-i, urea+elemental sulphur+zeolite incorporated; U_NBPTCuZ-i, urea $+\mathrm{NBPT}+\mathrm{Cu}+$ zeolite incorporated; U, urea; Super N, NBPT-coated urea; FH Nitro Mais, urea coated with B and Cu; FH Nitro Gold, urea coated with polymer and elemental sulphur; AS, ammonium sulfate; and C, control treatment without fertilizer. 
of average reduction of $50-78 \%$ in $\mathrm{N}$ volatilization under NBPT-coated urea, compared to commercial urea, were observed under field conditions (Scivittaro et al., 2010; Soares et al., 2012; Nascimento et al., 2013; Stafanato et al., 2013). These results indicate that NBTP is an efficient additive for reducing N volatilization, but also that the incorporation of the additives into urea granules, performed in this study, was even more efficient in the control of $\mathrm{N}$ losses by volatilization, possibly due to the homogeneous contact between the inhibitor and urea in the granules promoted by the incorporation. Thus, whereas in humid soil conditions, surface coating disintegrates fast, making urea molecules more susceptible to urease action, the incorporation of the additives prevent this from happening.

The higher $\mathrm{N}$ volatilization in the formulation $\mathrm{U}_{-}$ BCuZ-I, compared to U_BCu-i, in this study, indicates

Table 2. Total N-NH${ }_{3}$ volatilized, and leaching of N-NH4 $4^{+}$ and $\mathrm{N}-\mathrm{NO}_{3}{ }^{-}$in the soil columns evaluated with different commercial $\mathrm{N}$ fertilizers and urea-based laboratory formulations ${ }^{(1)}$.

\begin{tabular}{lccccc}
\hline Fertilizer ${ }^{(2)}$ & $\begin{array}{c}\text { Total N-NH } \\
\text { volatilized } \\
\text { (mg per column) }\end{array}$ & $\begin{array}{c}\text { Volatilized } \\
\text { proportion } \\
(\%)\end{array}$ & \multicolumn{3}{c}{$\begin{array}{c}\text { Mineral N leached } \\
\text { (mg per column) }\end{array}$} \\
\cline { 4 - 7 } C & $0.7 \mathrm{a}$ & 0.3 & $1.4 \mathrm{a}$ & $2.9^{\text {ns }}$ & $4.3 \mathrm{a}$ \\
AS & $3.7 \mathrm{a}$ & 3.7 & $2.2 \mathrm{a}$ & 4.0 & $6.2 \mathrm{a}$ \\
U_NBPT-i & $7.4 \mathrm{a}$ & 3.5 & $2.2 \mathrm{a}$ & 2.5 & $4.7 \mathrm{a}$ \\
U_BCu-i & $9.7 \mathrm{a}$ & 9.7 & $2.1 \mathrm{a}$ & 3.2 & $5.3 \mathrm{a}$ \\
U_NBPTZ-i & $13.9 \mathrm{a}$ & 6.6 & $7.1 \mathrm{c}$ & 2.2 & $9.3 \mathrm{~b}$ \\
U_BCuZ-i & $19.5 \mathrm{~b}$ & 9.2 & $4.1 \mathrm{~b}$ & 2.7 & $6.8 \mathrm{a}$ \\
FH Nitro Mais & $22.3 \mathrm{~b}$ & 10.6 & $3.7 \mathrm{~b}$ & 3.1 & $6.8 \mathrm{a}$ \\
Super N & $24.4 \mathrm{~b}$ & 11.6 & $2.8 \mathrm{a}$ & 3.7 & $6.5 \mathrm{a}$ \\
U_Cu-i & $27.6 \mathrm{~b}$ & 13.1 & $2.1 \mathrm{a}$ & 3.5 & $5.6 \mathrm{a}$ \\
U_SZ-i & $32.6 \mathrm{c}$ & 15.6 & $3.4 \mathrm{a}$ & 2.7 & $6.1 \mathrm{a}$ \\
U_NBPTCuZ-i & $38.0 \mathrm{c}$ & 18.2 & $4.0 \mathrm{~b}$ & 2.3 & $6.3 \mathrm{a}$ \\
U_NBPTCu-i & $39.9 \mathrm{c}$ & 18.9 & $2.1 \mathrm{a}$ & 2.6 & $4.7 \mathrm{a}$ \\
U_S-i & $44.1 \mathrm{c}$ & 20.9 & $3.1 \mathrm{a}$ & 2.6 & $5.7 \mathrm{a}$ \\
FH Nitro Gold & $50.0 \mathrm{~d}$ & 23.2 & $2.9 \mathrm{a}$ & 2.6 & $5.5 \mathrm{a}$ \\
U_Z-i & $54.2 \mathrm{~d}$ & 25.7 & $2.9 \mathrm{a}$ & 3.4 & $6.3 \mathrm{a}$ \\
U & $56.6 \mathrm{~d}$ & 26.8 & $4.8 \mathrm{~b}$ & 3.8 & $8.6 \mathrm{~b}$ \\
\hline Mean & 27.9 & - & 3.1 & 3.0 & 6.2 \\
CV (\%) & 21.3 & - & 43.3 & 29.4 & 26.4 \\
\hline
\end{tabular}

(1)Means followed by the same letter do not differ by the Scott-Knott test at $5 \%$ probability. ${ }^{(2)}$ Refer to Table 1 for the description of the fertilizers. ${ }^{\mathrm{n} N}$ Nonsignificant. a negative effect of zeolite. The ion $\mathrm{Cu}^{+2}$ has affinity for zeolite negative charges, as described by Kocaoba et al. (2007) and Calvo et al. (2009). Stoichiometric calculations showed that the amount of zeolite in this formulation is capable to retain around $4.4 \mathrm{~g} \mathrm{~kg}^{-1} \mathrm{Cu}^{+2}$ of the final product. Since the formulation U_BCuZ-i has $1.17 \mathrm{~g} \mathrm{~kg}^{-1} \mathrm{Cu}^{+2}$, part of the $\mathrm{Cu}$ might have been retained in the negative charges of zeolite and, therefore, it was not available for inhibiting urease activity in the soil.

The inclusion of clay minerals in fertilizers mixture has spread up in the last few years in Brazil. It aims to bind the nutrients in order to delay their release into the soil solution. However, no satisfactory results were observed here, with the mixture of urea and zeolite (U_Z-i). Stoichiometric analysis shows that the contribution of zeolite CEC $\left(140 \mathrm{cmol}_{c} \mathrm{dm}^{-3}\right)$ for retaining ammonium is relatively small, around $25 \mathrm{~g} \mathrm{dm}^{-3} \mathrm{NH}_{4}{ }^{+}$. Considering that the laboratorydeveloped formulations have $20 \%$ of zeolite, the amount of $\mathrm{NH}_{4}^{+}$bound to be retained is very low, around $5.0 \mathrm{~g} \mathrm{dm}^{-3}$ of the final product. Thus, there is no significant effect of zeolite inclusion on $\mathrm{N}$ volatilization. This inefficiency has been reported previously by Tarkalson \& Ippolito (2011), who concluded that zeolite (clinoptilolite) did not influence the retention of ammonium in swine manure, probably due to the adsorption competition by other cations. Moreover, Faria et al. (2013) did not observe any effect of coating urea with zeolites on $\mathrm{N}$ volatilization, compared to commercial urea.

The clinoptilolite zeolite has a specific surface of only $11.4 \mathrm{~m}^{2} \mathrm{~g}^{-1}$, according to the BET method. This and the small amount of zeolite used in the mixture (20\%) can justify the lack of efficiency of the clay mineral in controlling $\mathrm{N}$ losses. However, Werneck et al. (2012) reported a $69 \%$ reduction in $\mathrm{N}$ volatilization due to clinoptilolite coating or incorporation into urea granules, compared to commercial pearly urea. This supports the notion that zeolite has some influence on volatilization inhibition, due to the zeolite capacity to decrease $\mathrm{NH}_{4}^{+}$concentration in the soil solution; but the real mechanism of inhibition is not clearly known yet.

Coating urea with other compounds, like elemental $\mathrm{S}$, can theoretically reduce volatilization, since it would reduce $\mathrm{pH}$ around the fertilizer granule in the soil (Saik, 1995). However, this study's results did not prove that, and small reduction was observed in Nitro Gold 
(urea coated with elemental S). Other studies have also showed that urea covered with sulfur does not reduce ammonia losses by volatilization (Faria et al., 2014; Oliveira et al., 2014). The laboratory-incorporated formulations with elemental S and zeolite (U_S-i and U_SZ-i) showed a better result than Nitro Gold. Nascimento et al. (2013) observed that S-coated urea reduced $\mathrm{N}$ losses by $50 \%$, but the authors reported lack of rain for around 15 days after fertilizer application, which may have favored microbial S oxidation and the acidification of the environment around urea granules in the soil.

In general, the laboratory-developed formulations were able to inhibit ammonium losses by leaching, when compared to urea (Table 2). However, small N contents as ammonium were found in the leaching solution, in all urea formulations evaluated. The laboratory-incorporated formulation U_NBPTZ-i had the highest ammonium loss by leaching; and commercial urea, U_NBPTCuZ-i, FH Nitro Mais, and U_BCuZ-i were statistically similar, with greater ammonium losses by leaching than U_Z-i, FH Nitro Gold, U_S-i, U_NBPTCu-i, U_SZ-i, U_Cu-i, Super N, U_BCu-i, U_NBPT-i, and AS (Table 2).

Nitrate losses by leaching were very low, and there was no significant difference between urea formulations (Table 2). The total mineral $\mathrm{N}$ leached (ammonium + nitrate) was lower in the laboratorydeveloped formulations (except U_NBPTZ-i) and in the commercial formulations with urease inhibitors than in commercial urea. Up to $9.3 \mathrm{mg} \mathrm{N}$ per column was percolated to layers deeper than 0.45 after four simulated precipitations, in the worst treatment (U_NBPTZ-i). This amount is substantial, considering the whole crop cycle, specially in rainy seasons.

Many studies have reported significant nitrate leaching losses in agricultural soils (Ghiberto et al., 2009; Dourado-Neto et al., 2010; Yang et al., 2015). However, according to Oliveira et al. (2007), N losses by leaching in Brazilian soils are very low in most of the situations.

In general, the formulations with the lowest $\mathrm{N}$ volatilization had also the lowest mineral $\mathrm{N}$ leaching (Table 2). However, U_NBPTZ-i formulation showed the highest $\mathrm{N}-\mathrm{NH}_{4}^{+}$leaching.

The presence of zeolite with the additives $\mathrm{B}$ and $\mathrm{Cu}^{+2}$ (U_BCuZ_i) reduced $\mathrm{NH}_{4}{ }^{+}$leaching and, therefore, this clay mineral contributes to soil ammonium retention, due to its negative charges (Andrade et al., 2010).

The reduction in nitrate leaching by urease inhibitors can also be significant, although it is not their main purpose. This study observed small amounts of nitrate leaching through the soil (mean of $3.0 \mathrm{~kg} \mathrm{ha}^{-1}$ ), which did not differ between the evaluated sources (Table 2). Sanz-Cobena et al. (2012) evaluated the topdressing application of NBPT-coated urea in maize and observed that the inhibitor was able to reduce $\mathrm{N}$ leaching by $47 \%$ compared to commercial urea. More specific researches reported that most of the leached $\mathrm{N}$ comes from mineralized organic matter (Roberts et al., 2011). But in this study, this probably was not the case, since the study considered only four simulated light rain events, in four consecutive days.

The upper layers $(0-0.10$ and $0.10-0.20 \mathrm{~m})$ accumulated less $\mathrm{N}_{-} \mathrm{NH}_{4}{ }^{+}$than the deepest one $(0.20-0.45 \mathrm{~m})$. Most of the laboratory-developed formulations had a uniform ammonium distribution through soil profile (Table 3). The accumulated ammonium differed between sources only in the layer of $0.10-0.20 \mathrm{~m}$, where the values under U_Z-i and U_NBPTZ-i, although not significantly different from commercial urea $(\mathrm{U})$, were higher than the other sources tested.

The amount of $\mathrm{N}-\mathrm{NO}_{3}{ }^{-}$accumulated in the soil profile was much higher than $\mathrm{N}^{-} \mathrm{NH}_{4}^{+}$, for all formulations (Table 3). The highest $\mathrm{N}_{-} \mathrm{NO}_{3}{ }^{-}$accumulation occurred in the upper layers $(0-0.10$ and $0.10-0.20 \mathrm{~m})$, and U_BCuZ-i stood out. The formulations U_NBPT-i, U_S-i, U_NBPTCu-i, U_Cu-i, U_SZ-i, U_NBPTCuZ-i and the commercial Super $\mathrm{N}$ also had significant nitrate accumulations in the upper layers, much higher than other formulations tested and than control.

Total mineral $\mathrm{N}$ in the soil profile, down to $0.45-\mathrm{m}$ depth, was higher for sources that left more $\mathrm{N}^{-\mathrm{NO}_{3}}{ }^{-}$ in the upper layers, notably U_BCuZ- i (Table 3), and decreased following the order: U NBPT-i, U_NBPTCu-i, U_S-i, U_SZ-i, U_Cu-i, U_NBPTCZ-i, and commercial Super N. The other laboratorydeveloped formulations and commercial sources left lower mineral $\mathrm{N}$ in the profile.

The low $\mathrm{N}^{-} \mathrm{NH}_{4}{ }^{+}$accumulation in the soil profile can be related to the intense nitrification of this amide source with increased $\mathrm{pH}$ around the granule due to the hydrolysis of the urea-based fertilizers (Chien et al., 2009). The accumulated $\mathrm{N}_{-} \mathrm{NH}_{4}{ }^{+}$in the soil profile (from 1.0 to $4.3 \mathrm{~kg} \mathrm{ha}^{-1}$ ) were similar to those reported 
Table 3. $\mathrm{N}^{-\mathrm{NH}_{4}}{ }^{+}$and $\mathrm{N}-\mathrm{NO}_{3}{ }^{-}$accumulation $\left(\mathrm{mg} \mathrm{dm}^{-3}\right)$ in different soil layers with the application of different nitrogen commercial fertilizers and urea-based laboratory formulations ${ }^{(1)}$.

\begin{tabular}{|c|c|c|c|c|c|c|c|}
\hline \multirow[t]{2}{*}{ Fertilizer } & \multicolumn{2}{|c|}{$0-0.10 \mathrm{~m}$} & \multicolumn{2}{|c|}{$0.10-0.20 \mathrm{~m}$} & \multicolumn{2}{|c|}{$0.20-0.45 \mathrm{~m}$} & \multirow[t]{2}{*}{ Total } \\
\hline & $\mathrm{N}-\mathrm{NH}_{4}^{+}$ & $\mathrm{N}-\mathrm{NO}_{3}^{-}$ & $\mathrm{N}-\mathrm{NH}_{4}{ }^{+}$ & $\mathrm{N}^{-\mathrm{NO}_{3}}{ }^{-}$ & $\mathrm{N}-\mathrm{NH}_{4}^{+}$ & $\mathrm{N}-\mathrm{NO}_{3}^{-}$ & \\
\hline $\mathrm{C}$ & $1.1^{\mathrm{ns}}$ & $1.9 \mathrm{a}$ & $1.1 \mathrm{a}$ & $2.0 \mathrm{a}$ & $3.0^{\text {ns }}$ & $4.6^{\mathrm{ns}}$ & $13.8 \mathrm{a}$ \\
\hline AS & 2.2 & $4.9 \mathrm{a}$ & $1.0 \mathrm{a}$ & $2.5 \mathrm{a}$ & 3.6 & 8.9 & $21.1 \mathrm{a}$ \\
\hline U_NBPT-i & 1.5 & $17.1 \mathrm{~b}$ & $1.7 \mathrm{a}$ & $20.2 b$ & 2.8 & 7.2 & $50.4 \mathrm{~b}$ \\
\hline U_BCu-i & 1.6 & $6.5 \mathrm{a}$ & $1.2 \mathrm{a}$ & $8.3 \mathrm{a}$ & 1.7 & 4.5 & $23.8 \mathrm{a}$ \\
\hline U_NBPTZ-i & 1.7 & $3.6 \mathrm{a}$ & $2.9 \mathrm{~b}$ & $3.3 \mathrm{a}$ & 3.8 & 5.4 & $10.8 \mathrm{a}$ \\
\hline U_BCuZ-i & 3.7 & $31.9 \mathrm{c}$ & $2.2 \mathrm{a}$ & $24.6 \mathrm{~b}$ & 2.6 & 13.5 & $78.6 \mathrm{c}$ \\
\hline FH Nitro Mais & 1.5 & $4.3 \mathrm{a}$ & $1.3 \mathrm{a}$ & $2.8 \mathrm{a}$ & 4.0 & 7.4 & $21.3 \mathrm{a}$ \\
\hline Super N & 1.7 & $13.8 \mathrm{~b}$ & $2.0 \mathrm{a}$ & $20.5 b$ & 3.5 & 8.0 & $49.9 \mathrm{~b}$ \\
\hline U_Cu-i & 1.4 & $15.2 \mathrm{~b}$ & $1.5 \mathrm{a}$ & $12.5 \mathrm{a}$ & 4.4 & 6.6 & $41.7 \mathrm{~b}$ \\
\hline U_SZ-i & 1.6 & $17.6 \mathrm{~b}$ & $1.9 \mathrm{a}$ & $10.2 \mathrm{a}$ & 2.3 & 10.9 & $44.5 \mathrm{~b}$ \\
\hline U_NBPTCuZ-i & 1.5 & $14.5 \mathrm{~b}$ & $1.5 \mathrm{a}$ & $7.9 \mathrm{a}$ & 4.2 & 7.9 & $37.5 b$ \\
\hline U_NBPTCu-i & 2.1 & $14.8 \mathrm{~b}$ & $1.6 \mathrm{a}$ & $14.7 \mathrm{~b}$ & 4.4 & 10.3 & $47.8 \mathrm{~b}$ \\
\hline U_S - i & 2.3 & $18.4 \mathrm{~b}$ & $1.3 \mathrm{a}$ & $10.2 \mathrm{a}$ & 3.9 & 8.9 & $45.0 \mathrm{~b}$ \\
\hline FH Nitro Gold & 2.2 & $4.5 \mathrm{a}$ & $1.5 \mathrm{a}$ & $3.7 \mathrm{a}$ & 3.6 & 6.4 & $21.8 \mathrm{a}$ \\
\hline U_Z- i & 2.3 & $8.6 a$ & $3.5 b$ & $7.6 \mathrm{a}$ & 4.3 & 6.3 & $32.5 \mathrm{a}$ \\
\hline $\mathrm{U}$ & 2.7 & $7.8 \mathrm{a}$ & $2.8 \mathrm{~b}$ & $6.4 \mathrm{a}$ & 3.4 & 6.0 & $28.9 \mathrm{a}$ \\
\hline Mean & 2.0 & 11.6 & 1.7 & 8.0 & 3.5 & 7.7 & 34.5 \\
\hline $\mathrm{CV}(\%)$ & 56 & 46.9 & 55.6 & 83 & 63.4 & 57.8 & 40.8 \\
\hline
\end{tabular}

${ }^{(1)}$ Means followed by the same letter do not differ by the Scott-Knott test at $5 \%$ probability. ${ }^{(2)}$ Refer to Table 1 for the description of the fertilizers. ${ }^{\text {ns }}$ Nonsignificant.

by Primavesi et al. (2006) in equivalent soil layers. The authors, however, applied $200 \mathrm{~kg} \mathrm{ha}^{-1} \mathrm{~N}$ in a pasture, during a rainy period, which meant significantly different experimental conditions compared to this study (120 kg ha ${ }^{-1} \mathrm{~N}$, under controlled conditions).

$\mathrm{N}-\mathrm{NO}_{3}{ }^{-}$levels (Table 3 ) accumulated in surface layers $(0-0.10$ and $0.10-0.20 \mathrm{~m})$, especially for the sources with lower volatilization (Table 2), which preserved more $\mathrm{N}$ in the soil. When evaluating ammonium and nitrate contents in soil, at the $51^{\text {st }}$ day after the application of commercial urea and ammonium sulfate in corn cultivation, Lara Cabezas \& Souza (2008) found similar patterns of nitrate and ammonium distribution using urea+ammonium sulfate and urea+agricultural gypsum, which decreased in the soil profile. Mariano et al. (2013), evaluating the mineralized $\mathrm{N}$ by aerobic incubation down to $0.60-\mathrm{m}$ depth, observed that the highest mineralization rate was found at the $0-0.20 \mathrm{~m}$ layer. The authors attributed this result to the higher organic matter content and to the greater activity of microorganisms in this layer.
It should be highlighted that the total and the organic $\mathrm{N}$ accumulated in soil profile were not evaluated here. This information could help explain the fate of $\mathrm{N}$ over time and evaluate the hipothesys that, actually, a substantial amount of $\mathrm{N}$ from fertilizers may be immobilized in the soil layers, even in a sandy soil with low organic matter content, as the one used in this study.

\section{Conclusions}

1. The new laboratory-developed formulations, with the incorporation of urease inhibitors (NBPT, $\mathrm{H}_{3} \mathrm{BO}_{3}$, and $\mathrm{Cu}$ ) into the urea granules, are more efficient in reducing $\mathrm{N}$ volatilization losses than commercial fertilizers coated with these same additives, showing similar results to ammonium sulfate.

2. The addition of zeolite in the laboratorydeveloped formulations containing urease inhibitors and elemental sulphur does not reduce $\mathrm{N}$ volatilization; and no promising results were observed for $\mathrm{N}$ leaching. 
3. Ammonium and nitrate leaching and total $\mathrm{N}$ mineral accumulation in the soil profile are not affected by the urease inhibitors.

\section{Acknowledgments}

To Fundação de Amparo à Pesquisa do Estado de São Paulo (Fapesp, process No. 2012/11442-1), for the scholarship granted.

\section{References}

ANDRADE, J.C.R. de A.; LOIOLA, A.R.; SILVA, L.R.D. da.; ROMERO, R.E. Avaliação da liberação de $\mathrm{NH}_{4} \mathrm{NO}_{3}$ ocluido em zeólita 4A a partir de soluções salinas. Química Nova, v.33, p.1692-1697, 2010. DOI: 10.1590/S0100-40422010000800014.

BERNARDI, A.C. de C.; PAIVA, P.R.P.; MONTE, M.B. de M. Produção de matéria seca e teores de nitrogênio em milho para silagem adubado com uréia misturada a zeólita. São Carlos: Embrapa Pecuária Sudeste, 2007. (Embrapa Pecuária Sudeste. Comunicado técnico, 77).

BRASIL. Ministério da Agricultura, Pecuária e do Abastecimento. Manual de métodos analíticos oficiais para fertilizantes minerais, orgânicos, organominerais e corretivos. Brasília, 2007. 141p.

BRUNAUER, S.; EMMETT, P.H.; TELLER, E. Adsorption of gases in multiolecular layers. Journal of the American Chemical Society, v.60, p 309-319, 1938. DOI: 10.1021/ ja01269a023.

CALVO, B.; CANOIRA, L.; MORANTE, F.; MARTÍNEZBEDIA, J.M.; VINAGRE, C.; GARCÍA-GONZÁLEZ, J.-E.; ELSEN, J.; ALCANTARA, R. Continuous elimination of $\mathrm{Pb}^{2+}$, $\mathrm{Cu}^{2+}, \mathrm{Zn}^{2+}, \mathrm{H}^{+}$and $\mathrm{NH}_{4}{ }^{+}$from acidic waters by ionic exchange on natural zeolites. Journal of Hazardous Materials, v.166, p.619627, 2009. DOI: 10.1016/j.jhazmat.2008.11.087.

CANCELLIER, E.L.; SILVA, D.R.G.; FAQUIN, V.; GONÇALVES, B. de A.; CANCELLIER, L.L.; SPEHAR, C.R. Ammonia volatilization from enhanced-efficiency urea on nomaize in brazilian cerrado with improved soil fertility. Ciência e Agrotecnologia, v.40, p.133-144, 2016. DOI: 10.1590/141370542016402031115 .

CANTARELlA, H.; TRIVELIN, P.C.O.; CONTIN, T.L.M.; DIAS, F.L.F.; ROSSETO, R.; MARCELINO, R.; COIMBRA, R.B.; QUAGGIO, J.A. Ammonia volatilisation from urease inhibitor-treated urea applied to sugarcane trashblankets. Scientia Agricola, v.65, p.397-401, 2008. DOI: 10.1590/S010390162008000400011.

CHIEN, S.H.; PROCHNOW, L.I.; CANTARELLA, H. Recent developments of fertilizer production and use to improve nutrient efficiency and minimize environmental impacts. Advances in Agronomy, v.102, p.267-322, 2009. DOI: 10.1016/ S0065-2113(09)01008-6.
DOURADO-NETO, D.; POWLSON, D.; ABU BAKAR, R.; BACCHI, O.O.S.; BASANTA, M.V.; THI CONG, P.; KEERTHISINGHE, G.; ISMAILI, M.; RAHMAN, S.M.; REICHARDT, K.; SAFWATI, M.S.A.; SANGAKKARA, R.; TIMM, L.C.; WANG, J.Y.; ZAGAL, E.; KESSEL, C. van. Multiseason recoveries of organic and inorganic nitrogen-15 in tropical cropping systems. Soil Science Society of America Journal, v.74, p.139-152, 2010. DOI: 10.2136/sssaj2009.0192.

DU, C.; TANG, D.; ZHOU, J.; WANG, H.; SHAVIV, A. Prediction of nitrate release from polymer-coated fertilizers using an artificial neural network model. Biosystems Engineering, v.99, p.478-486, 2008. DOI: 10.1016/j.biosystemseng.2007.12.003.

EMBRAPA; UNIVERSIDADE DE SÃO PAULO. José Carlos Polidoro; Ioná Rech; Paulo Sérgio Pavinato. Fertilizante à base de ureia micronizada e seu processo de obtenção. Int. $\mathrm{Cl}$.: C05C 9/00. BR 102015001331 0, 21 jan. 2015, 2 ago. 2016.

FARIA, L. de A.; NASCIMENTO, C.A.C. do; VENTURA, B.P.; FLORIM, G.P.; LUZ, P.H. de C.; VITTI, G.C. Hygroscopicity and ammonia volatilization losses from nitrogen sources in coated urea. Revista Brasileira de Ciência do Solo, v.38, p.942948, 2014. DOI: 10.1590/S0100-06832014000300026.

FARIA, L. de A; NASCIMENTO, C.A.C. do; VITTI, G.C.; LUZ, P.H. de C.; GUEDES, E.M.S. Loss of ammonia from nitrogen fertilizers applied to maize and soybean straw Revista Brasileira de Ciência do Solo, v.37, p.969-975, 2013. DOI: 10.1590/S0100-06832013000400014.

FRANKENBERGER JR., W.T.; TABATABAI, M.A. Amidase and urease activities in plants. Plant and Soil, v.64, p.153-166, 1982. DOI: $10.1007 / \mathrm{BF} 02184247$.

GHIBERTO, P.J.; LIBARDI, P.L.; BRITO, A.S.; TRIVELIN, P.C.O. Leaching of nutrients from a sugarcane crop growing on an Ultisol in Brazil. Agricultural Water Management, v.96, p.1443-1448, 2009. DOI: 10.1016/j.agwat.2009.04.020.

HEFFER, P.; PRUD'HOMME, M. Fertilizer Outlook 20152019. Paris: IFA, 2015. $83^{\text {rd }}$ IFA Annual Conference Istanbul (Turkey), 25-27 May 2015. Available at: $<$ http://www.fertilizer. org/imis20/images/Library_Downloads/2015_ifa_istanbul_ summary.pdf? WebsiteKey $=411$ e $9724-4$ bda-422f-abfc8152 ed 74 f $306 \&=404 \% 3$ bhttp $\% 3 a \% 2$ f $\% 2$ fwww.fertilizer. org\%3a80\%2fen\%2fimages\%2fLibrary_Downloads\%2f2015 ifa_istanbul_summary.pdf>. Accessed on: Mar. 142017.

KAMOGAWA, M.Y; TEIXEIRA, M.A. Autoamostrador de baixo custo para análise por injeção em fluxo. Química Nova, v.32, p.1644-1646, 2009. DOI: 10.1590/S010040422009000600048.

KELliHER, F.M.; CLOUGH, T.J.; CLARCK, H.; RYS, G.; SEDCOLE, J.R. The temperature dependence of dicyandiamide (DCD) degradation in soils: a data synthesis. Soil Biology and Biochemistry, v.40, p.1878-1882, 2008. DOI: 10.1016/j. soilbio.2008.03.013.

KOCAOBA, S.; ORHAN, Y.; AKYÜZ, T. Kinetics and equilibrium studies of heavy metal ions removal by use of natural zeolite. Desalination, v.214, p.1-10, 2007. DOI: 10.1016/j. desal.2006.09.023. 
LARA CABEZAS, A.R.; TRIVELIN, P.C.O.; BENDASSOLLI, J.A.; SANTANA, D.G. de; GASCHO, G.J. Calibration of a semi-open static collector for determination of ammonia volatilization from nitrogen fertilizers. Communications in Soil Science and Plant Analysis, v.30, p.389-406, 1999. DOI: 10.1080/00103629909370211.

LARA CABEZAS, W.A.R.; SOUZA, M.A. Volatilização de amônia, lixiviação de nitrogênio e produtividade de milho em resposta a aplicação de misturas de uréia com sulfato de amônio ou com gesso agrícola. Revista Brasileira de Ciência do Solo, v.32, p.2331-2342, 2008. DOI: 10.1590/S010006832008000600012 .

MARIANO, E.; TRIVELIN, P.C.O.; LEITE, J.M.; MEGDA, M.X.V.; OTTO, R.; FRANCO, H.C.J. Incubation methods for assessing mineralizable nitrogen in soils under sugarcane. Revista Brasileira de Ciência do Solo, v.37, p.450-461, 2013. DOI: $10.1590 /$ S0100-06832013000200016.

NASCIMENTO, C.A.C. do; VITTI, G.C.; FARIA, L. de A.; LUZ, P.H.C.; MENDES, F.L. Ammonia volatilization from coated urea forms. Revista Brasileira de Ciência do Solo, v.37, p.1057-1063, 2013. DOI: 10.1590/S0100-06832013000400022.

NÖMMIK, H. The effect of pellet size on the ammonia loss from urea applied to Forest soil. Plant and Soil, v.39, p.309-318, 1973. DOI: $10.1007 / \mathrm{BF} 00014798$.

OLIVEIRA, J.A. de; STAFANATO, J.B.; GOULART, R. de S.;; ZONTA, E.; LIMA, E.; MAZUR, N.; PEREIRA, C.G.; SOUZA, H.N. de; COSTA, F.G.M. Volatilização de amônia proveniente de ureia compactada com enxofre e bentonita, em ambiente controlado. Revista Brasileira de Ciência do Solo, v.38, p.15581564, 2014. DOI: 10.1590/S0100-06832014000500021.

OLIVEIRA, P.P.A.; TRIVELIN, P.C.O.; OLIVEIRA, W.S. de. Balanço de nitrogênio $\left({ }^{15} \mathrm{~N}\right)$ da uréia nos componentes de uma pastagem de capim-marandu sob recuperação em diferentes épocas de calagem. Revista Brasileira de Zootecnia, v.36, p.1982-1989, 2007. DOI: 10.1590/S1516-35982007000900006.

OLSEN, K.K. Multiple wavelength ultraviolet Determinations of nitrate concentration, method comparisons from the Preakness brook monitoring project, October 2005 to October 2006. Water, Air, and Soil Pollution, v.187, p.195-202, 2008. DOI: 10.1007/ s11270-007-9508-8.

PRIMAVESI, O.; PRIMAVESI, A.C.; CORRÊA, L. de A.; SILVA, A.G. da; CANTARELLA, H. Lixiviação de nitrato em pastagem de coastcross adubada com nitrogênio. Revista Brasileira de Zootecnia, v.35, p.683-690, 2006. DOI: 10.1590/ S1516-35982006000300008.

RAIJ, B. van; ANDRADE, J.C. de; CANTARELLA, H.; QUAGGIO, J.A. (Ed.). Análise química para avaliação da fertilidade de solos tropicais. Campinas: IAC, 2001. 285p.

RICHARDS, L.A. (Ed.). Diagnosis and improvement of saline and alkali soils. Washington: Usda, 1954. 160p. (Usda. Agriculture Handbook, 60).

ROBERTS, T.L.; ROSS, W.J.; NORMAN, R.J.; SLATON, N.A.; WILSON JR, C.E. Predicting nitrogen fertilizer needs for rice in Arkansas using alkaline hydrolyzable-nitrogen. Soil Science
Society of America Journal, v.75, p.1161-1171, 2011. DOI: 10.2136/sssaj2010.0145.

ROCHETTE, P.; ANGERS, D.A.; CHANTIGNY, M.H.; GASSER, M.-O.; MACDONALD, J.D.; PELSTER, D.E.; BERTRAND, N. $\mathrm{NH}_{3}$ volatilization, soil $\mathrm{NH}_{4}^{+}$concentration and soil $\mathrm{pH}$ following subsurface banding of urea at increasing rates. Canadian Journal of Soil Science, v.93, p.261-268, 2013. DOI: $10.4141 /$ cjss2012-095.

SAIK, R.D. The evolution of a sulphur bentonite fertilizer: one company's perspective. Sulphur in Agriculture, v.19, p.74-77, 1995.

SANZ-COBENA, A.; SÁNCHEZ-MARTÍN, L.; GARCÍATORRES, L.; VALLEJO, A. Gaseous emissions of $\mathrm{N}_{2} \mathrm{O}$ and $\mathrm{NO}$ and $\mathrm{NO}_{3}$ - leaching from urea applied with urease and nitrification inhibitors to a maize (Zea mays) crop. Agriculture, Ecosystems and Environment, v.149, p.64-73, 2012. DOI: 10.1016/j.agee.2011.12.016.

SCIVITTARO, W.B.; GONÇALVES, D.R.N.; VALE, M.L.C. do; RICORDI, V.G. Perdas de nitrogênio por volatilização de amônia e resposta do arroz irrigado à aplicação de ureia tratada com o inibidor de uréase NBPT. Ciência Rural, v.40, p.12831289, 2010. DOI: 10.1590/S0103-84782010000600007.

SILVA, F.C. da. (Ed.). Manual de análises químicas de solos, plantas e fertilizantes. 2.ed. rev. e ampl. Brasília: Embrapa, 2009. 627p.

SOARES, J.R.; CANTARELLA, H.; MENEGALE, M.L. de C. Ammonia volatilization losses from surface-applied urea with urease and nitrification inhibitors. Soil Biology and Biochemistry, v.52, p.82-89, 2012. DOI: 10.1016/j. soilbio.2012.04.019.

STAFANATO, J.B.; GOULART, R. de S.; ZONTA, E.; LIMA, E.; MAZUR, N.; PEREIRA, C.G.; SOUZA, H.N. de. Volatilização de amônia oriunda de ureia pastilhada com micronutrientes em ambiente controlado. Revista Brasileira de Ciência do Solo, v.37, p.726-732, 2013. DOI: 10.1590/S0100-06832013000300019.

TARKALSON, D.D.; IPPOLITO, J.A. Clinoptilolite zeolite influence on nitrogen in a manure-amended sandy agricultural soil. Communications in Soil Science and Plant Analysis, v.42, p.2370-2378, 2011. DOI: 10.1080/00103624.2011.605495.

TASCA, F.A.; ERNANI, P.R.; ROGERI, D.A.; GATIBONI, L.C.; CASSOL, P.C. Volatilização de amônia do solo após a aplicação de ureia convencional ou com inibidor de urease. Revista Brasileira de Ciência do Solo, v.35, p.493-502, 2011. DOI: 10.1590/S0100-06832011000200018.

TRENKEL, M.E. Slow and controlled release and stabilized fertilizers: an option for enhancing nutrient use efficiency in agriculture. $2^{\text {nd }}$ ed. Paris: International Fertilizer Industry Association, 2010. 160p.

WATSON, C.J.; AKHONZADA, N.A.; HAMILTON, J.T.G.; MATHEWS, D.I. Rate and mode of application of the urease inhibitor $N$-(n-butyl) thiophosphoric triamide on ammonia volatilization from surface-applied urea. Soil Use and Management, v.24, p.246-253, 2008. DOI: 10.1111/j.14752743.2008.00157.x. 
WERNECK, C.G.; BREDA, F.A.; ZONTA, E.; LIMA, E.; POLIDORO, J.C.; BALIEIRO, F. de C.; BERNARDI, A.C. de C. Volatilização de amônia proveniente de ureia com zeolita natural. Pesquisa Agropecuária Brasileira, v.47, p.466-470, 2012. DOI: 10.1590/S0100-204X2012000 300020 .
YANG, X; LU, Y.; TONG, Y.; YIN, X. A 5-year lysimeter monitoring of nitrate leaching from wheat-maize rotation system: comparison between optimum $\mathrm{N}$ fertilization and conventional farmer N fertilization. Agriculture, Ecosystems and Environment, v.199, p.34-42, 2015. DOI: 10.1016/j. agee.2014.08.019.

Received on April 14, 2016 and accepted on December 26, 2016 